San Jose State University

SJSU ScholarWorks

Faculty Publications

Accounting and Finance

January 2011

\title{
Absorptive Capacity at the Individual Level: Linking Creativity to Innovation in Academia
}

Ashley R. Davis

San Jose State University, adavis@ou.edu

N. Da Silva

San Jose State University

Follow this and additional works at: https://scholarworks.sjsu.edu/acc_fin_pub

Part of the Business Commons

\section{Recommended Citation}

Ashley R. Davis and N. Da Silva. "Absorptive Capacity at the Individual Level: Linking Creativity to Innovation in Academia" The Review of Higher Education (2011): 355-379.

This Article is brought to you for free and open access by the Accounting and Finance at SJSU ScholarWorks. It has been accepted for inclusion in Faculty Publications by an authorized administrator of SJSU ScholarWorks. For more information, please contact scholarworks@sjsu.edu. 
The Review of Higher Education

Spring 2011, Volume 34, No. 3, pp. 355-379

Copyright $\odot 2011$ Association for the Study of Higher Education

All Rights Reserved (ISSN 0162-5748)

\section{Absorptive Capacity at the Individual Level: Linking Creativity to Innovation in Academia}

\section{Nancy Da Silva and Ashley R. Davis}

Research scholarship among university faculty is important in most university settings because it ensures the currency and relevance of the concepts that faculty teach. Research scholarship can also serve as a potential source of additional revenue in extramural grant and contract funding and can impact the university's prestige (Armstrong \& Sperry, 1994; Hagstrom, 1971). Thus, numerous studies have been conducted examining factors that influence research productivity among university faculty. Researchers have investigated demographic variables, individual difference characteristics, and institutional characteristics in relation to number of publications (Bellas \& Toutkoushian, 1999; Blackburn, Bieber, Lawrence, \& Trautvetter, 1991; Blackburn \& Lawrence, 1995; Maske, Durden, \& Gaynor, 2003; Santo et al., 2009; Snell, Engstrom, Reetz, Schweinle, \& Reed, 2009). While we have gained a good deal of knowledge from previous research, many of the findings are

NANCY DA SILVA is an Associate Professor in the Department of Organization and Management, San Jose State University. ASHLEY R. DAVIS is an Assistant Professor in the Department of Accounting and Finance, San Jose State University. ACKNOWLEDGMENTS: We would like to thank Greg R. Oldham, Lois E. Tetrick, Jennifer Hutcheson, Robert Hicks, and Chris Foreman for their helpful comments on earlier drafts of this manuscript. Address queries to Nancy Da Silva, San Jose State University, One Washington Square, San Jose, CA 95192-0070; telephone: (408) 924-7798; fax: (408) 924-3555; email: Nancy.Dasilva@sjsu.edu. 


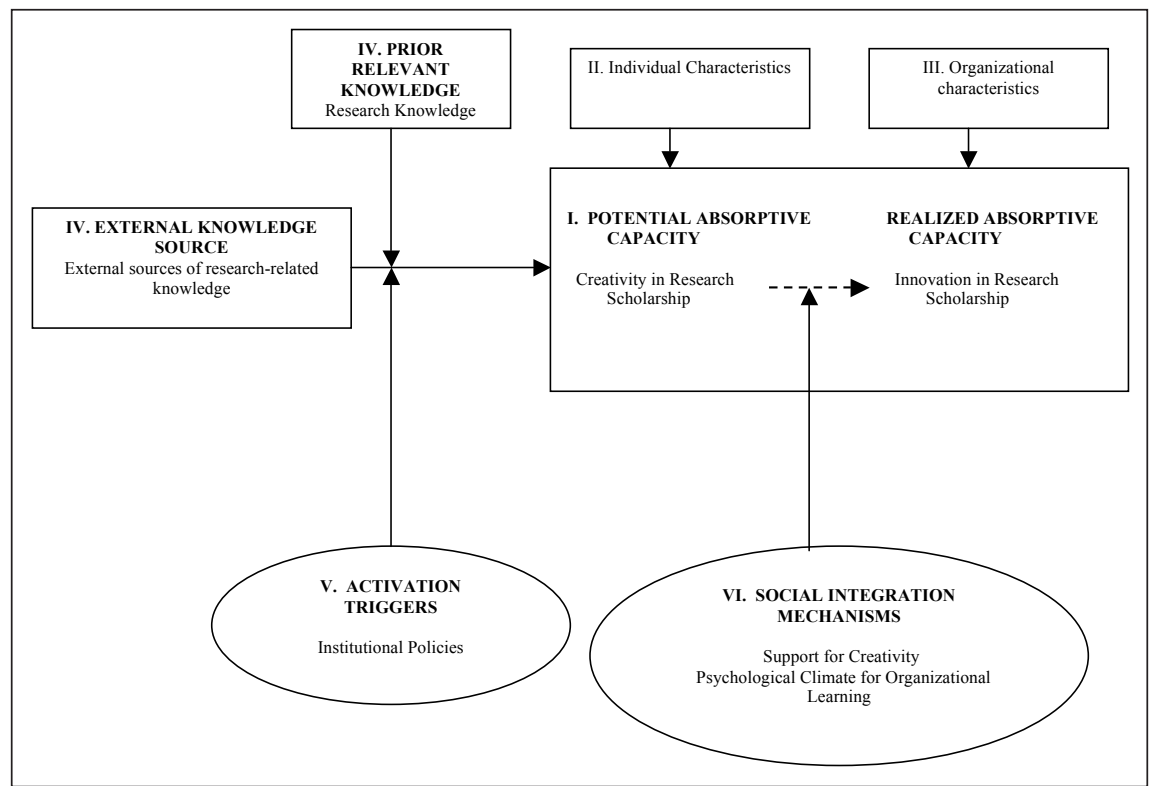

Figure 1. Proposed theoretical framework. Note: Adapted from Zabra \& George (2002, p. 192).

conflicting and inconclusive. Furthermore, much of the previous research has not been hypothesis driven.

This article examines research scholarship through the lens of Zahra and George's (2002) model of absorptive capacity, which helps us understand how existing expertise and knowledge are used to gain new knowledge that can be applied to the development of creative research ideas. Figure 1 is a depiction of our framework, which includes propositions based on Zahra and George's model and which also integrates the research on individual creativity and innovation in examining how research ideas develop into such research products as manuscripts and grant proposals.

This article offers several contributions to the literature on research productivity. First, it provides a theoretical framework to explain faculty scholarship by integrating research conducted in organizations on absorptive capacity, individual creativity and innovation, and organizational learning. Second, while previous research has focused on correlates of research productivity, this framework separates research productivity into two stages: the generation of research ideas and the implementation of those ideas that results in published manuscripts. We propose that the generation of research ideas has a different set of antecedents than the implementation of those ideas and that to understand why some faculty publish more then others requires 
examining these two stages separately. Third, the framework incorporates concepts that have not been examined in previous research (e.g., support for creativity, organizational learning) that may provide additional insight into why some faculty are more productive in research than others. Furthermore, the framework incorporates higher order relationships such as moderators to provide a more comprehensive view of predicting research productivity, an aspect that only a few studies have endeavored (e.g., Blackburn, Bieber, Lawrence, \& Trautvetter, 1991; Blackburn \& Lawrence, 1995).

We first briefly review the literature that has examined correlates of research productivity among university faculty. We then present a theoretical framework that attempts to explain and predict research productivity in a new way. Next, we discuss specific research questions that the framework suggests, followed by a discussion of our framework's implication for institutional leaders.

\section{LITERATURE REVIEW}

Numerous empirical studies have been conducted investigating predictors of faculty research productivity. However, the findings are fraught with inconsistencies. Teodorescu (2000) and Levin and Stephan (1989) found a negative relationship between age and research productivity, which would suggest that younger faculty are more productive than older faculty; however, Christensen and Jansen (1992), Bayer and Dutton (1977), Over (1982), and Snell, Sorenson, Rodriguez, and Kuanliang (2009) found no support for this relationship. Research productivity has also been hypothesized to differ between men and women. However, numerous studies have not found this to be the case (e.g., Bailey, 1992; Blackburn, Behymer, \& Hall, 1978; Cameron \& Blackburn, 1981; Clemente 1973; Teodorescu, 2000). In contrast, other studies have found that there are indeed differences (Bellas \& Toutkoushian, 1999; Maske, Durden, \& Gaynor, 2003). Furthermore, some studies explain the differences due to the presence of other factors such as the number of years in academia (Snell et al., 2009) or through indirect effects such as selfcompetence (Blackburn, Bieber, Lawrence, \& Trautvetter, 1991) and perceived control (Perry et al., 2000).

Academic rank has shown to be positively related to research productivity in some studies (Blackburn, Behymer, \& Hall, 1978; Kelly, 1986; Linsky \& Straus, 1975; Sheehan \& Welch, 1996) but not others (Christensen \& Jansen, 1992; Lawrence \& Blackburn, 1985; Snell et al., 2009; Teodorescu, 2000). Christensen and Jansen (1992) found no relation between tenure and research productivity, while Teodorescu (2000) found a positive relationship.

Numerous studies have also examined institutional characteristics in relation to faculty productivity with regard to research. Several studies found that faculty who perceived institutional support for research were more productive 
than those who did not perceive support (e.g., Baird, 1991; Fox, 1985; McGee \& Ford, 1987; Wanner, Lewis, \& Gregorio, 1981). Furthermore, researchers (Blackburn \& Lawrence, 1995; Christensen \& Jansen, 1992; Long, Crawford, White, \& Davis, 2009; Perry, Clifton, Menec, Struthers, \& Menges, 2000; Teodorescu, 2000) found that research productivity was higher in institutions that emphasized research as part of the university's mission.

There are numerous reasons for the inconsistent and discrepant findings. Some studies examined faculty from only one discipline (e.g., Christensen \& Jansen, 1992), whereas other studies surveyed faculty across multiple disciplines within the same university (e.g., Schultz \& Chung, 1988), and still others surveyed faculty from multiple disciplines across multiple universities (e.g., Teodorescu, 2000).

Furthermore, research productivity has been operationalized differently across studies. Teodorescu (2000) used self-reported number of publication counts, while Tien and Blackburn (1996) looked at number of publications during the two years prior to the study. Volkwein and Carbone (1994) examined grant applications submitted, counted the number of external grants received, and had a panel review each faculty member's curriculum vitae. Kelly (1986) computed a productivity score by looking at eight variables (e.g., number of journal articles, research grants, successfully chaired doctoral committees) and then divided her sample into low- and high-producing faculty.

Due to the inconsistent findings from previous research, we approach faculty research productivity from a new perspective-that of absorptive capacity, a concept that is popular in predicting organizational innovation. We hope that this approach leads to the testing of new hypotheses that will further an understanding in higher education of research scholarship.

\section{Networking ANd Attending Conferences}

While many of the research findings have been inconsistent, one has emerged about the importance of networking and attending conferences. Christensen and Jansen (1992) examined five categories of predictors: (a) interest in research, (b) research preparation, (c) demographic variables, (d) work environment, and (e) assigned work load in relation to research activity by industrial education faculty. They appraised these five predictor categories in relation to three indices of research productivity: (a) a quantitative measure of publication output during a five-year period, (b) a quantitative measure of research studies conducted during a three-year period, and (c) a dichotomous ("yes" or "no") measure of whether respondents had received external research funds during the three-year period immediately preceding the study. 
Christensen and Jansen (1992) found that funding, summer workload, institutional mission, research interest, graduate teaching, and advising student research were significant predictors of at least one measure of research productivity. Networking, which they defined as the extent to which participants communicated with faculty at other institutions regarding research-related activities, was the only factor that was significantly related to all three outcome measures of research productivity. Participants who stated that they were in "daily communication with faculty at other institutions averaged approximately twice as many publications as did those who communicated weekly or monthly with other faculty. They also had three times the publication output as those who communicated quarterly" (p. 28).

Teodorescu (2000) conducted a comprehensive cross-national study of faculty productivity. Individual demographic variables (e.g., age, gender), individual achievement variables (e.g., tenure status, number of national conferences), and institutional characteristics (e.g., salary, quality of students) were examined as predictors of faculty publication productivity in 10 countries. Teodorescu found that correlates of faculty productivity differed markedly across the nations; however, attending conferences outside and within the respondent's country were consistent correlates of productivity as was receiving financial support for research.

Although the study was cross-sectional and therefore could not make definitive causal conclusions, Teodorescu suggested that receiving research support to attend conferences, work on grants, and have time for research leads to higher publication productivity, especially among young scholars. However, this study, like other studies examining correlates of research productivity, did not investigate the underlying reasons for such findings.

Past research suggests that networking and attending conferences may be more predictive of research scholarship than factors such as faculty rank, gender, and salary. One potential reason for these findings is that the former factors develop a scholar's absorptive capacity, which is critical to the development of research ideas and to the production of grant applications and published articles. The following section describes Zahra and George's (2002) framework of absorptive capacity in relation to research productivity.

\section{Absorptive Capacity}

March and Simon (1958) suggested that most innovations within an organization result from borrowing rather than invention. Consistent with this proposition, Cohen and Levinthal (1990) argued that a company's ability to exploit outside sources of knowledge is crucial for a company to be innovative. They further suggested that a company's ability to use external knowledge is mainly a function of the company's level of prior related knowledge, which "is necessary in order for a company to recognize the value of new infor- 
mation, assimilate it, and apply it to commercial ends" (p. 128). Cohen and Levinthal term this set of abilities "absorptive capacity." The main premise of absorptive capacity is that prior related knowledge is needed to assimilate and use new knowledge (Cohen \& Levinthal, 1990).

For example, an organization that has a great deal of experience and knowledge in product development is considered to have a high absorptive capacity in the product development domain. A high absorptive capacity firm is postulated to be more innovative in terms of product development, for example, than an organization that has little or no knowledge of the product development field because the low absorptive capacity firm will be unable to assess and apply new information critical in developing products. Likely, it will not even recognize the value of this new information (Deeds, 2001). Thus, Cohen and Levinthal stressed the importance of an organization's ability to learn and act on scientific discoveries and technical activities that occur outside the firm (Cohen \& Levinthal, 1990).

Although most of the theoretical and empirical development of the concept of absorptive capacity has occurred at the country, interorganization, and organization level of analysis (see Zahra \& George, 2002, for examples), we argue that these same propositions also operate at the individual level. Researchers who are aware of or utilize other researchers' ideas are more likely to be successful in their research program than researchers who are not exposed to the ideas of others. Furthermore, a researcher's ability to exploit these external sources of research-related knowledge is a function of that researcher's prior research-related knowledge.

\section{Absorptive Capacity at the Individual Level}

Although Cohen and Levinthal (1990) discussed absorptive capacity as it relates to innovation at the organizational level, they acknowledged that their concept of absorptive capacity is based on research at the individual level. They suggested that prior relevant knowledge improves an individual's memory, learning, and problem-solving ability.

Empirical research on memory has shown that individuals are better able to store and recall information if they have prior knowledge of the topic (e.g., Barfield, 1986; Chiesi, Spilich, \& Voss, 1979; Spilich, Vesonder, Chiesi, \& Voss, 1979). In addition, Anderson, Farrell, and Sauers (1984) found that students who had familiarity with the programming language Pascal learned a new programming language, LISP, much more effectively than students who had no experience with computer programming. Research has also found prior knowledge to be useful in problem solving (Larkin, 1981; Priest \& Lindsay, 1992; Voss, Greene, Post, \& Penner, 1983).

These empirical findings support associative network models (e.g., Anderson, 1976; Collins \& Loftus, 1975; Norman \& Rumelhart, 1975; Quillian, 1968, 1969), which theorize that there is an associative structure for knowledge 
such that knowledge is organized into semantic networks, where sections of the network contain related pieces of information. Hence, new concepts and information are linked with related preexisting concepts in long-term memory. Information in long-term memory will become more available as a function of the richness or number of associations that can be made (Wickens, Gordon, \& Liu, 1997). And according to Bradshaw, Langley, and Simon (1983) and Simon (1985), it is this prior relevant knowledge that gives rise to creativity because this prior knowledge permits linkages that may not have been considered before.

Cohen and Levinthal's (1990) conceptualization of absorptive capacity is based on research in associative network models and the related area of expert-novice distinctions. However, the proposed framework and the hypotheses presented below expand on Cohen and Levinthal's conceptualization and incorporate additional concepts based on Zahra and George's (2002) reconceptualization of absorptive capacity. Thus, the premise underlying cognitive theories of expert-novice differences is an important component in the proposed framework but is only one part of the framework.

\section{The Zahra and George Reconceptualization}

Although Cohen and Levinthal's (1990) definition of absorptive capacity is often cited, several other researchers have developed their own conceptualizations. For example, Kim (1998) suggested that absorptive capacity refers to an organization's ability to learn and solve problems. By integrating previous research on absorptive capacity, Zahra and George (2002) developed a new definition of absorptive capacity, which they defined as a "set of organizational routines and processes by which firms acquire, assimilate, transform, and exploit knowledge to produce a dynamic organizational capability" (p. 186). They suggested that absorptive capacity is comprised of two subsets of processes: (a) potential absorptive capacity, which refers to an organization's knowledge acquisition and assimilation capabilities, and (b) realized absorptive capacity, which focuses on knowledge transformation and exploitation.

\section{Absorptive Capacity at the Individual LeVel}

Zahra and George's (2002) model of absorptive capacity delineates the conditions necessary for an organization to create and sustain a competitive advantage. We adapt their model to explain research scholarship at the individual level.

\section{Potential and Realized Absorptive Capacity}

Potential absorptive capacity according to Zahra and George (2002) refers to an organization's ability to identify, acquire, and assimilate external 
sources of knowledge. With respect to research scholarship, potential absorptive capacity would be an individual's ability to acquire and assimilate information that is useful for research scholarship. As such, an indicator of an individual's potential absorptive capacity would be his or her level of creative performance. Amabile (1988) defined creative performance as the "production of novel and useful ideas" (p. 126). Therefore, in academia, creative performance with respect to research scholarship could refer to the number of research ideas a faculty member generates.

In contrast, realized absorptive capacity-the second set of processes of absorptive capacity-is an individual's ability to transform and exploit this creative knowledge as products. This conceptualization is parallel to Amabile's (1988) definition of innovative performance, which she defined as the "successful implementation of creative ideas" (p. 126). Therefore, indicators of an individual's realized absorptive capacity in the domain of research would be the number of journal articles published, rather than the number of journal articles written. This definition observes Amabile's focus on successful implementation.

This is an important distinction that previous researchers have not acknowledged. Some faculty are talented at developing new research ideas and hypotheses but for numerous reasons do not develop them into finished products such as journal manuscripts or grant submissions. This framework attempts to identify the factors that predict potential and realized absorptive capacity as well as the factors that moderate this relationship.

A substantial amount of research exists, examining individual and organizational characteristics that can enhance or diminish an individual's level of creative and innovative performance (e.g., Amabile, 1983; Feist, 1999; Oldham \& Cummings, 1996). Thus, the framework we propose incorporates individual and organizational characteristics in predicting creative and innovative performance. The distinction between creative and innovative performance is important because factors that influence creativity may differ from those that influence innovation. Van de Ven and Angle (1989) suggested that innovation is a social process because it involves the implementation of ideas, and implementation relies heavily on the involvement of others, while being creative does not necessarily require the involvement of others.

Previous research provides some support for this argument. Axtell, Homan, Unsworth, Wall, Waterson, and Harrington (2000) examined the extent to which shopfloor employees generated suggestions (i.e., creative performance) and implemented these suggestions (i.e., innovative performance). Consistent with the propositions discussed above, Axtell and her colleagues found that individual-level variables, such as self-efficacy, were better predictors of generating suggestions than group and organizational characteristics. Conversely, group and organizational characteristics, such as support for innovation, were better predictors in implementing these suggestions than 
individual-level variables. Therefore, our proposed framework postulates that individual-level characteristics predict creative performance, whereas individual perceptions of organizational characteristics predict innovative performance.

\section{Individual Characteristics}

Proposition 1: Individual characteristics (i.e., creativity-relevant personality characteristics, task motivation, creativity-relevant skills, and research self-efficacy) predict a faculty member's ability to generate novel research ideas.

Numerous studies, across a wide range of settings, have been conducted examining the effects of personality on individuals' creativity (Feist, 1999). The general profile of a creative person is an individual who is independent, nonconformist, unconventional, likely to have wide interests, have greater openness to new experiences, and be more risk-taking (Martindale, 1989). Additional factors that have been linked to individual creativity are playfulness (Stein, 1991), hard work (Amabile, 2001), and confidence and autonomy (Axtell et al., 2000).

The Creative Personality Scale (CPS) developed by Gough (1979) is commonly used to assess an individual's creativity. Gough correlated the CPS score and creativity ratings for 12 groups of individuals such as architects and scientists and found significant positive correlations in 10 of the 12 groups. In addition, Gough examined two cross-validation samples and obtained similar findings. Several other studies have provided further validation of the instrument (Oldham \& Cummings, 1996; Zhou \& Oldham, 2001). For example, Oldham and Cummings (1996) assessed employees' creativityrelevant personal characteristics (CPS) and found that creative employees were more likely to submit patent disclosure forms to their organization than their noncreative counterparts. Therefore, Oldham and Cummings suggest that individuals who have a creative personality will be more likely to engage in creative behaviors.

In addition to personality characteristics, Amabile (1983) discussed the importance of examining domain-relevant skills, creativity-relevant skills, and task motivation in understanding individual creativity. These three components are the building blocks for Amabile's componential model of individual creativity and are incorporated into Ford's (1996) conceptualization of creative individual action.

The first component in Amabile's (1983) model are domain-relevant skills (discussed below) which are similar to Zahra and George's (2002) conceptualization of prior relevant knowledge. The second component is task motivation, which refers to an individual's intrinsic motivation and can be demonstrated by an individual's persistence (Taggar, 2002). For example, Amabile, Hill, Hennessey, and Tighe (1994) found that artists who were in- 
trinsically motivated showed greater commitment and devoted more time to task completion.

The final component is creative-thinking abilities, which is associated with a cognitive style in which individuals take new perspectives on problems (Amabile, 1983). For example, divergent thinking and associational skills are commonly studied creative abilities (Barron \& Harrington, 1981).

Another individual level factor related to creativity is self-efficacy. Selfefficacy is derived from Bandura's (1977) social learning theory and refers to an individual's belief that he or she has the capability of performing a specific task. When presented with a specific task, individuals with moderate to high self-efficacy are more likely to engage in task-related activities and persist longer when faced with adversity. This task frequency and persistence lead to more mastery experiences and further enhance self-efficacy. In contrast, individuals with low self-efficacy engage in fewer coping behaviors and give up more easily when faced with problems. As a result, they have less mastery and an increase in their low self-efficacy (Bandura, 1977, 1986).

Ford (1996) discussed how confidence in an individual's creative ability facilitates creative individual action, and several studies have found a positive relationship between self-efficacy and creativity (Axtell et al., 2000; Redmond, Mumford, \& Teach, 1993; Tesluk, Farr, \& Klein, 1997). For example, Axtell and associates (2000) demonstrated that self-efficacy was positively related to the number of proposed changes individuals suggested regarding various aspects of their work. Frese, Teng, and Wijnen (1999) also found that self-efficacy related to the number of ideas an individual submitted to an organization's suggestion program. Several researchers have also examined self-efficacy in an academic setting (Blackburn \& Lawrence, 1995; Landino \& Owen, 1988; Schoen \& Winocur, 1988; Vasil, 1992). For example, Vasil (1992) found research self-efficacy to be positively related to research productivity. Therefore, individuals who feel confident in performing tasks that relate to research scholarship are more likely to be creative in the context of research scholarship.

\section{Organizational Characteristics}

Proposition 2: Organizational characteristics (i.e., adequacy of research support and assigned workload) predict a faculty member's ability to publish his or her research ideas.

Several organizational characteristics have been examined in relation to innovative performance. For example, several researchers suggest that financial rewards may encourage individuals to submit their ideas to their organization (Frese, Teng, \& Wijnen, 1999; Tesluk, Farr, \& Klein, 1997). In relation to research productivity, Kelly (1986) found that faculty in institutions with a research focus were more productive researchers. Bean (1982) found that institutional factors, such as the granting of advanced degrees, 
institutional size, and centralization were influences on faculty productivity. Teordorescu (2000) examined institutional characteristics such as salary and hours spent weekly on teaching in relation to publication productivity. In addition, Fowler, Bushardt, and Brooking (1985) demonstrated that a school's status was also strongly related to the likelihood of its faculty to publish. Thus, numerous organizational characteristics have been linked to research productivity.

The framework we propose incorporates two commonly studied organizational characteristics: adequacy of research support and assigned workload. As discussed earlier, we postulate that individual characteristics predict creative performance (i.e., the development of novel and useful research ideas), while organizational characteristics predict innovative performance (i.e., successful implementation of research ideas such as a journal article). Thus, a faculty member needs the university's resources and support to translate his or her ideas into published manuscripts.

\section{External Knowledge Source and Prior Relevant Knowledge}

Proposition 3: An individual's use of external sources of research-related knowledge predicts creative performance above and beyond individual characteristics (i.e., creativity-relevant personality characteristics, task motivation, creativity-relevant skills, and research self-efficacy).

Proposition 4: An individual's prior relevant knowledge moderates the relationship between external sources of research-related knowledge and creative performance. Specifically, the relationship between external sources of research-related knowledge and creative performance will be stronger when an individual has prior relevant knowledge.

In addition to the predictors discussed above, the concept of absorptive capacity offers additional constructs that may be useful in predicting creative and innovative performance. Zahra and George (2002) suggested that exploitation of external knowledge sources is an important antecedent to potential absorptive capacity. The assumption is that, the greater a firm's exposure to diverse and complementary external sources of knowledge, the greater the firm's opportunity to develop its potential absorptive capacity. At the organizational level, external sources can include acquisitions, interorganizational relationships such as R\&D consortia, and alliances (Zahra \& George, 2002). In addition, Zahra and George suggested that past experience or prior relevant knowledge, as articulated earlier by Cohen and Levinthal (1990), also influences the development of potential absorptive capacity.

In relation to research scholarship, adopting an absorptive capacity approach suggests that a focal way in which individuals are able to develop research ideas is to exploit others' research ideas and that individuals who have related knowledge are the most likely to benefit from exposure to the knowledge of others. This does not suggest that researchers should "steal" 
their colleagues' ideas to advance their own research program but rather that researchers need to interact with other researchers, formally or informally to help generate new ideas. Formally, a researcher may be able to exploit others' research ideas by reading their articles and attending their conference presentations. Informally, a researcher could benefit from others' ideas by having some connection or relationship with other researchers, which then gives the focal individual access to their ideas. The informal route may imply the need for background similarity and the willingness of others to share ideas.

Research at the organizational level has found that firms that are similar to one another are more successful in interorganizational learning than dissimilar firms (Lane \& Lubatkin, 1998). Therefore, at the individual level, research in relational demography may be useful in examining these assertions. It may be that individuals who are similar in demographic characteristics such as age and gender or in personality characteristics may be more likely to interact with one another and thus develop relationships, which may aid in the generation of research ideas.

However, according to Cohen and Levinthal (1990) and Zahra and George (2002), in order for an individual to fully benefit from external sources of research-related knowledge, he or she must have prior related knowledge. Research has shown that an individual's learning of new knowledge is greatest when it is related to the individual's existing knowledge structure (Bower \& Hilgard, 1981; Ellis, 1965; Estes, 1970). This idea also has been extended into the creativity domain. The notion of prior relevant knowledge is similar to the domain-relevant knowledge component in Amabile's (1988) theory of individual creativity. She argued that domain-relevant knowledge is critical to creative performance. To generate creative ideas, she argues, individuals must have factual knowledge and technical skills that are relevant to the domain of interest. More broadly described, these skills could include factual knowledge, knowledge of paradigms, and performance scripts for solving problems in the domain. Few studies have examined the role of domain-relevant skills in the production of creative work; however, Amabile and Gyrskiewicz (1987) interviewed 120 scientists and found that several skills, such as expertise in the subject area, enabled the scientists to produce creative work.

Thus, it can be argued that prior relevant knowledge moderates the relationship between external sources of research-related knowledge and creative performance. That is, new information from others may trigger creative ideas if the focal individual has prior relevant knowledge that permits links to be made.

\section{Activation Triggers}

Proposition 5: Activation triggers in the form of institutional policies moderate the relation between the use of external sources of research-related knowledge and creative performance. Specifically, the greater the number 
of requirements for research scholarship, the stronger the positive relation between the use of external sources of research-related knowledge and creative performance.

Our proposed framework also suggests that, in addition to the role of prior relevant knowledge in moderating the relationship between external sources of research-related knowledge and creative performance, there is a need for some type of activation trigger to encourage the individual to generate new ideas. Zahra and George (2002) argued that activation triggers moderate the impact of knowledge sources and experience on potential absorptive capacity. They define activation triggers as events that cause a firm to respond to specific internal or external stimuli.

In the academic setting, faculty who do not perceive research scholarship as important for their tenure and promotion may not be motivated to engage in research activity. In contrast, academic institutions that emphasize research provide faculty members with an impetus to develop research ideas. Although several studies have examined academic institutional policies and missions as correlates to research productivity, we have found no study that investigates institutional policies as a moderator. Therefore, we suggest that, moderating the relation between the use of external sources of research-related knowledge sources and creative performance, is whether institutional policies on retention, tenure, and promotion, emphasize research scholarship.

\section{Social Integration Mechanisms}

Zahra and George (2002) suggested that social integration mechanisms moderate the relation between potential and realized absorptive capacity. Social integration mechanisms are formal or informal processes that facilitate the sharing and exploitation of knowledge. Two potential social integration factors-support from work and nonwork sources and the climate for organizational learning - may facilitate the distribution of information and serve as potential moderators between creative and innovative performance. We argue that individuals who are in a supportive environment that encourages their creative research ideas and suggestions are more likely to develop these research ideas into innovative products such as journal publications and grant submissions. Similarly, individuals who are in an organizational learning environment that encourages innovation and risk-taking may be more likely to refine their research ideas into research products. Here is an overview of the research conducted in these two areas:

\section{Support for Creativity}

Proposition 6: Support for creativity from a supervisor moderates the relation between creative performance and innovative performance. Specifically, a stronger relation between creative performance and innovative performance exists for individuals who perceive support for their creative ideas from their supervisor. 
Proposition 7: Support for creativity from colleagues moderates the relation between creative performance and innovative performance. Specifically, a stronger relation between creative performance and innovative performance exists for individuals who perceive support for their creative ideas from their colleagues at their academic institution.

Proposition 8: Support for creativity from nonwork sources moderates the relation between creative performance and innovative performance. Specifically, a stronger relation between creative performance and innovative performance exists for individuals who perceive support for their creative ideas from their friends and family.

A substantial amount of research suggests that supervisor support is instrumental in eliciting creative behavior from subordinates (Amabile, Conti, Coon, Lazenby, \& Herron, 1996; Oldham \& Cummings, 1996; Scott \& Bruce, 1994; Tierney, Farmer, \& Graen, 1999). Oldham and Cummings (1996) found that supportive supervision was positively related to the number of patent disclosures written by employees. Tierney, Farmer, and Graen (1999) found that employees who had a positive relationship with their supervisors were more creative in the workplace. Redmond, Mumford, and Teach (1993) demonstrated that subordinates who were exposed to supervisors who encouraged them to view problems in alternative ways and to spend more time thinking about the problems produced more creative solutions than subordinates who did not have such supervisors. Scott and Bruce (1994) found that a high leader-subordinate relationship (characterized by trust, mutual liking, and respect) produced a high level of innovative behavior from the subordinates. Therefore, it is not surprising that Yong (1994) suggested that one of the most significant parts for encouraging a creative climate is a trusting relationship between supervisor and subordinate.

In an academic context, the department chair would be the position that is most parallel to the organizational definition of a supervisor. However, the concept of supervisor could be examined further to include support from the college dean, the provost, and from the university president. Measures of support across all levels of the academic institution is an avenue of research that has not been fully explored.

In addition, research has found that colleagues can also facilitate or inhibit the creativity of their peers. Creative thinking has been found in work groups that communicate well, are open to new ideas, and allow individuals to feel safe in voicing their ideas (Parnes \& Noller, 1972). Similarly, Amabile, Conti, Coon, Lazenby, and Herron (1996) and Madjar, Oldham, and Pratt (2002) have found that individuals were more creative if their co-workers were supportive and encouraging.

Although there is not a great deal of research examining the effect of nonwork support on creativity, Madjar, Oldham, and Pratt (2002) suggest that nonwork sources, such as family and friends outside the organization, 
can contribute to an individual's creativity at work. For instance, research has shown that supportive parents result in children being more creative in childhood as well as in adulthood (Harrington, Block, \& Block, 1987; Walberg, Rasher, \& Parkerson, 1980) and Madjar, Oldham, and Pratt (2002) found that support from family members and friends impacted employees' positive moods, which in turn enhanced their level of workplace creativity.

\section{The Psychological Climate for Organizational Learning.}

Proposition 9: The psychological climate for organizational learning moderates the relation between creative performance and innovative performance. Specifically, a stronger relationship between creative performance and innovative performance exists for individuals who perceive their institution as having a climate for organizational learning.

In addition to investigating support for creativity as a moderator, our proposed framework incorporates the psychological climate for organizational learning as a moderator of the creative performance and innovative performance relationship. Organizational learning is the process of improving actions within organizations through better knowledge and understanding (Fiol $\&$ Lyles, 1985). Companies that engage in organizational learning encourage their employees to learn, innovate, take risks, and question established ways of solving problems. There are numerous conceptualizations of organizational learning; however, this article focuses on Senge's (1990) conceptualization, given its popularity in the organizational learning literature (Crossan, Lane, White, \& Djurfeldt, 1995) and the qualitative research that has been conducted supporting the conceptualization.

Senge (1990) proposed five disciplines that characterize the practices of a learning organization: systems thinking, shared vision, team learning, managing mental models, and personal mastery. He defined systems thinking as "a discipline for seeing wholes" (p. 68) —in other words, examining overall patterns rather than isolated parts. It also involves recognizing that many things are connected in the world; therefore, rather than seeing a problem as caused by someone or something external, systems thinking perceives our actions as contributing to the problems we experience. Cohen and Levinthal (1990) suggest that individuals in an organization need to know where useful complementary expertise resides within and outside the organization: "This sort of knowledge can be knowledge of who knows what, who can help with what problem, or who can exploit new information" (p. 133). Cohen and Levinthal's notion is a feature of systems thinking. Individuals who are able to see and understand how the organization works internally and externally are able to capitalize on this knowledge in their development of research projects.

Shared vision, as defined by Senge (1990), refers to employees in an organization feeling bound together around a collective identity and sense of destiny. The discipline of building a shared vision occurs when employees 
truly believe they can shape the future of their organization. Therefore, rather than simply supporting an organizational vision that the employees feel was thrust upon them by top management, employees have the power to "paint the picture of what [they] want to create" (p. 231). Hence, the suggestion is that academic institutions that want faculty to conduct research need to build a shared vision with faculty members emphasizing research scholarship.

Team learning, Senge's third discipline, is a process in which team members work together to create the results its members desire. Organizations that engage in team learning encourage employees to speak freely and openly about their ideas without fear of criticism. Brown and Paulus (1996) found that individuals suggest relatively few ideas in brainstorming groups when they expect a critical evaluation of those ideas by other group members, and Holleran and Holleran (1976) suggested that group members must eliminate or prevent groupthink to foster individual creativity. In terms of academia, institutions that engage in team learning foster an environment that allows colleagues to openly discuss their research ideas without fear of being criticized and rejected. Mental models, according to Senge (1990), are the deeply ingrained assumptions and generalizations that every individual possesses. These assumptions can influence our behavior and our interpretation of everyday events.

The fourth discipline involves working with or managing these mental models. Managing mental models refers to the ability for individuals to be critical of their assumptions and the assumptions held by others. Thus, learning organizations foster an environment that allows individuals to be free to question the assumptions that underlie the decisions in the organization. Research has linked the concept of mental models with creativity. For example, Ford (1996) suggested that groups that recruit members who have diverse perspectives and skills and encourage critical thinking can facilitate creative behavior. Ford also recommended that leaders encourage critical thinking to allow alternative interpretations to be introduced, assumptions to be explored, and knowledge and creative abilities to be engaged. The suggestion is that academic institutions that encourage researchers to reflect on the assumptions that drive their research ideas as well as their colleagues' ideas will foster an environment that encourages critical thinking and the acceptance of diverse perspectives. This environment, in turn, facilitates creative behavior.

Finally, Senge's (1990) fifth discipline is personal mastery. Personal mastery involves two processes - the practice of clarifying what is important and continually learning to see current reality more clearly. Individuals who practice personal mastery are in a constant mode of learning. In learning organizations, employees are encouraged to become committed to lifelong learning and to the process of "continually clarifying and deepening our personal vision" (p. 7). Thus, academic institutions that encourage individu- 
als to continually learn and develop their research competencies may lead to more productive faculty.

Senge (1990) suggested that organizations need to foster a climate in which employees are able to practice these five disciplines. Organizations need to create a supportive environment where it is "safe for people to create visions, where inquiry and commitment to the truth are the norm, and where challenging the status quo is expected" (p. 172).

\section{Research Questions Derived from Our Framework}

This framework brings to light many research questions that will expand our understanding of faculty productivity. Since this framework separates a faculty member's ability to generate research ideas from his or her ability to publish his or her ideas, we can empirically test such questions as: What are key factors in predicting a faculty member's ability to generate novel research ideas? And what are key factors in predicting a faculty member's ability to publish his or her research ideas?

Furthermore, our framework suggests that there are moderators of this relationship, thus leading to such questions as: To what extent does the support for creativity from various sources (e.g., department chair, colleagues) moderate the relationship between a faculty member's generating ideas to getting his or her ideas published? And does a university's climate for organizational learning facilitate a faculty member's ability to develop ideas that he or she generates?

We can also examine the role that a faculty member's research knowledge plays in research scholarship. We can investigate the extent to which being current on the latest research and methodologies enables faculty to generate and develop novel research ideas. And what role do external sources of research-related knowledge contribute to a faculty member's ability to generate research ideas?

\section{ConClusion}

This framework provides a novel approach to outlining a process by which faculty are creative and innovative. Applying an organizational concept (absorptive capacity) to an individual-level problem (research productivity) may help us better understand individual creativity and innovativeness in the academic setting. The absorptive capacity framework (Zahra and George, 2002) allows us to draw a more complete nomological net that includes individual characteristics, organizational characteristics, institutional policies, research knowledge, and external sources of research-related knowledge to perhaps more accurately predict creativity and innovation in research scholarship. The propositions contained provide guidance for understanding the role that each concept plays in research scholarship. 
The generalizability of the framework may be hindered because it deals explicitly with the research productivity of university faculty members-a distinctive and potentially limiting setting. However, it seems plausible that business organizations may face the same challenges as universities in fostering creativity and innovation.

Innovation in for-profit organizations is a source of competitive advantage and is essential if organizations are to prosper (Damanpour \& Schneider, 2006). As traditionally studied in management, innovation in organizations refers to whether the organization is able to bring new products to market. However, innovation can be more broadly defined to include the implementation of ideas, products, or procedures that are novel and useful for the organization (Amabile, 1996). Thus, innovation can be radical (i.e., developing a new product) but it can also be small and incremental (i.e., refining a work process) (Mumford \& Gustafson, 1998). With this broader definition, any employee in any job at any level of the organization can develop a creative idea that can ultimately end up being implemented (Shalley, Zhou, \& Oldham, 2004).

As such, an employee's ability to generate new ideas to improve the workplace (creativity) may well depend on his or her individual characteristics, prior relevant knowledge of the job, external sources of knowledge, and institutional or company policies. Likewise, the ability of that employee to get his or her idea implemented (innovation) may be contingent on organizational characteristics (i.e., adequacy of support for change and assigned workload). Thus, many of the elements of this framework may be applicable to other organizational settings. However, whether this framework is actually generalizable is an empirical question that needs to be tested.

Our proposed framework presents three categories of implications for institutional leaders: selection, training, and organizational culture. This framework suggests that certain individual characteristics (creativity-relevant personality characteristics, task motivation, creativity-relevant skills, and research self efficacy) may be useful in predicting faculty creative performance (i.e., developing research ideas). If empirical data support this proposition (Proposition 1), then university hiring committees would want to select faculty who display these individual characteristics in addition to other criteria that selection committees currently use.

Furthermore, universities could provide training opportunities to enhance faculty's research knowledge base, both in their content area and in research methodology. Given the numerous demands faculty face to do research, teach, mentor students, and provide community service, it becomes difficult for faculty to keep abreast of the latest literature in their content area and be proficient with the latest qualitative and quantitative methods required to publish their research. Training workshops would not only enable faculty to better integrate external sources of research-related knowledge that they acquire 
from journal articles, conferences, and meetings but it would also improve their research self-efficacy, which has been shown to be positively related to research productivity (Blackburn \& Lawrence, 1995; Vasil, 1992).

Furthermore, as we have suggested, absorptive capacity relies on the ability to assimilate external knowledge. Therefore, universities should provide faculty with opportunities to network within the university as well as outside the university by providing funding for faculty to attend conferences and meetings. If funding is limited, providing faculty with podcasts or webcasts of the conferences may partially fill this need.

In a broader perspective, the university's culture can play a significant role in impacting research scholarship. Institutional policies (activation triggers in our framework) should support and emphasize research. Research productivity is oftentimes a requirement for tenure; but once faculty have reached tenure, there is often little external motivation or incentive to continue conducting research. This is particularly true in comprehensive universities and colleges in which faculty are encouraged and oftentimes expected to conduct research but which is not their main objective, as it is for their counterparts in research and doctoral universities. University administrators could develop a system to reward faculty who conduct research (e.g., \$2,000 for a peer-reviewed journal publication) or through lower course loads. These incentives could potentially increase faculty motivation and provide impetus for faculty to move their ideas from paper to product. Furthermore, these incentives would send a message regarding the importance that research plays in the university, a factor that has been found to be related to research productivity (Blackburn \& Lawrence, 1995; Christensen and Jansen, 1992; Long et al., 2009; Perry et al., 2000; Teodorescu, 2000).

Our framework also incorporates Zahra and George's concept of social integration mechanisms, which we developed in terms of support for creativity and organizational learning-two factors that previous research in this area has not explored. We proposed that support for creativity and a climate for organizational learning moderate the relationship between creative performance (generating research ideas) and innovative performance (turning these ideas into published manuscripts). One way in which universities could support creativity and learning would be to provide opportunities for faculty to present their research ideas and papers. For instance, faculty could present their research ideas in department meetings or college forums. Another option would be for faculty to distribute copies of their unpublished manuscript to their colleagues to review in a roundtable discussion that would provide useful feedback prior to submission. These suggestions will be most successful in universities that provide faculty with a nonthreatening and psychologically safe environment. Specifically, if faculty are encouraged and supported by their colleagues to voice their research ideas and to share their unpublished manuscripts without fear of being criticized and rejected, 
then these forums can serve as a useful social support mechanism to facilitate the research process.

In conclusion, increasing research productivity among faculty is an elusive goal for many educational institutions. This framework provides a new way of understanding the antecedents of faculty research productivity. By understanding the factors that contribute to research scholarship, institutional leaders can better foster a culture that supports and nurtures research productivity. We hope that absorptive capacity theory will provide academia with a better understanding of research scholarship.

\section{REFERENCES}

Amabile, T. M. (1983). Social psychology of creativity: A componential conceptualization. Journal of Personality and Social Psychology, 45, 357-377.

Amabile, T. M. (1988). A model of creativity and innovation in organizations. In B. M. Staw \& L. L. Cummings (Eds.), Research in organizational behavior (Vol. 10, pp. 123-167). Greenwich, CT: JAI.

Amabile, T. M. (1996). Creativity in context. Boulder, CO: Westview Press.

Amabile, T. M. (2001, April). Beyond talent. American Psychologist, pp. 333-336.

Amabile, T. M., Conti, R., Coon, H., Lazenby, J., \& Herron, M. (1996). Assessing the work environment for creativity. Academy of Management Journal, 39(5), $1154-1184$.

Amabile, T. M., \& Gyrskiewicz, S. S. (1987). Creativity in the R\&D laboratory (Technical Report \#30). Greensboro, NC: Center for Creative Leadership.

Amabile, T. M., Hill, K. G., \& Hennessey, B. A., \& Tighe, E. (1994). The Work Preference Inventory: Assessing intrinsic and extrinsic motivation orientations. Journal of Personality and Social Psychology, 66, 950-967.

Anderson, J. R. (1976). Language, memory, and thought. Hillsdale, N.J.: Erlbaum.

Anderson, J. R., Farrell, R., \& Sauers, F. (1984). Learning to program in LISP. Cognitive Science, 8(2), 87-129.

Armstrong, J. S., \& Sperry, T. (1994, March-April). The omsbudsman: Business school prestige-research versus teaching. Interfaces, 13-43.

Axtell, C. M., Homan, D. J., Unsworth, K. L., Wall, T. D., Waterson, P. E., \& Harrington, E. (2000). Shopfloor innovation: Facilitating the suggestion and implementation of ideas. Journal of Occupational and Organizational Psychology, 73(3), 265-285.

Bailey, T. G. (1992). Faculty research productivity. Minneapolis, MN: Association for the Study of Higher Education Annual Meeting. (ERIC Document Reproduction Service No. ED352895).

Baird, L. L. (1991). Publication productivity in doctoral research departments: Interdisciplinary and intradisciplinary factors. Research in Higher Education, 32(3), 303-318.

Bandura, A. (1977). Social learning theory. Englewood Cliffs, NJ: Prentice-Hall. Bandura, A. (1986). Social foundations of thought and action: A social cognitive theory. Englewood Cliffs, NJ: Prentice-Hall. 
Barfield, W. (1986). Expert-novice differences for software: Implications for problemsolving and knowledge acquisition. Behaviour and Information Technology, $5,15-29$.

Barron, F., \& Harrington, D. M. (1981). Creativity, intelligence and personality. In M. R. Rosenzweig \& L. W. Porter (Eds.), Annual review of psychology (Vol. 32, pp. 439-476). Palo Alto, CA: Annual Reviews.

Bayer, A. E., \& Dutton, J. E. (1977). Career age and research-professional activities of academic scientists: Tests of alternative nonlinear models and some implications for higher education faculty policies. The Journal of Higher Education, 48(3), 259-282.

Bean, J. P. (1982). A causal model offaculty research productivity. Bloomington: Indiana University. (ERIC Document Reproduction Service No. 216-661).

Bellas, M. L., \& Toutkoushian, R. K. (1999). Faculty time allocations and research productivity: Gender, race, and family effects. The Review of Higher Education, 22(4), 367-390.

Blackburn, R. T., Behymer, C. E., \& Hall, D. E. (1978). Research note: Correlates of faculty publications. Sociology of Education, 51(2), 132-141.

Blackburn, R. T., Bieber, J. P., Lawrence, J. H., \& Trautvetter, L. (1991). Faculty at work: Focus on research, scholarship, and service. Research in Higher Education, 32(4), 385-413.

Blackburn, R. T., \& Lawrence, J. H. (1995). Faculty at work: Motivation, expectation, satisfaction. Baltimore, MD: The Johns Hopkins University Press.

Bower, G. H., \& Hilgard, E. R. (1981). Theories of learning. Englewood Cliffs, NJ: Prentice-Hall.

Bradshaw, G. F., Langley, P. W., \& Simon, H. A. (1983, December). Studying scientific discovery by computer simulation. Science, 971-975.

Brown, V., \& Paulus, P. B. (1996). A simple dynamic model of social factors in group brainstorming. Small Group Research, 27, 91-114.

Cameron, S. W., \& Blackburn, R. T. (1981). Sponsorship and academic career success. The Journal of Higher Education, 52(4), 369-377.

Chiesi, H. L., Spilich, G. J., \& Voss, J. F. (1979). Acquisition of domain-related information in relation to high- and low-domain knowledge. Journal of Verbal Learning and Verbal Behavior, 18(3), 257-273.

Christensen, K. W., \& Jansen, D. G. (1992). Correlates of research productivity for industrial education faculty. Journal of Industrial Teacher Education, 29(4), 23-40.

Clemente, F. (1973). Early career determinants of research productivity. American Journal of Sociology, 79(2), 409-419.

Cohen, W. M., \& Levinthal, D. A. (1990). Absorptive capacity: A new perspective on learning and innovation. Administrative Science Quarterly, 35, 128-152.

Collins, A. M., \& Loftus, E. F. (1975). A spreading activation theory of semantic processing. Psychological Review, 82(6), 407-428.

Crossan, M. M., Lane, H. W., White, R. E., \& Djurfeldt, L. (1995). Organizational learning: Dimensions for a theory. International Journal of Organizational Analysis, 3(4), 337-360. 
Damanpour, F., \& Schneider, M. (2006). Phases of the adoption of innovation: Effects of environment, organization and top managers. British Journal of Management, 17(3), 215-236.

Deeds, D. L. (2001). The role of R\&D intensity, technical development and absorptive capacity in creating entrepreneurial wealth in high technology start-ups. Journal of Engineering and Technology Management, 18(1), 29-47.

Ellis, H. C. (1965). The transfer of learning. New York: Macmillan.

Estes, W. K. (1970). Learning theory and mental development. New York: Academic Press.

Feist, G. J. (1999). The influence of personality on artistic and scientific creativity. In R. Sternberg (Ed.), Handbook of creativity (pp. 273-296). New York: Cambridge University Press.

Fiol, C. M., \& Lyles, M. A. (1985). Organizational learning. Academy of Management Review, 10(4), 803-813.

Ford, C. (1996). A theory of individual creative action in multiple social domains. Academy of Management Review, 21(4), 1112-1142.

Fowler, A. R., Bushardt, S. C., \& Brooking, S. A. (1985). An analysis of the authorship in management-oriented journals: The relationship between school status, article type, publication outlet, and author academic position. Journal of Business Communication, 22(2), 25-36.

Fox, M. F. (1985). Publication, performance, and reward in science and scholarship. In J. C. Smart (Ed.), Higher Education: Handbook of Theory and Research (Vol. 1, pp. 255-282). New York: Agathon Press.

Frese, M., Teng, E., \& Wijnen, C. J. D. (1999). Helping to improve suggestion systems: Predictors of making suggestions in companies. Journal of Organizational Behavior, 20(7), 1139-1155.

Gough, H. G. (1979). A creative personality scale for the Adjective Check List. Journal of Personality and Social Psychology, 37(8), 1398-1405.

Hagstrom, W. O. (1971). Inputs, outputs, and the prestige of university science departments. Sociology of Education, 44, 375-397.

Harrington, D. M., Block, J. H., \& Block, J. (1987). Testing aspects of Carl Rogers's theory of creative environments: Child-rearing antecedents of creative potential in young adolescents. Journal of Personality and Social Psychology, 52(4), 851-856.

Harris, D. H. (1994). Organizatonal linkages: Understanding the productivity paradox. Washington, DC: National Academy Press.

Holleran, B. P., \& Holleran, P. R. (1976). Creativity revisited: A new role for group dynamics. Journal of Creative Behavior, 10(2), 130-137.

Kelly, M.E. (1986). Enablers and inhibitors to research productivity among high and low producing vocational education faculty members. Journal of Vocational Education Research, 11(4), 63-80.

Kim, L. (1998). Crisis construction and organizational learning: Capability building in catching-up at Hyundai Motor. Organization Science, 9(4), 506-521.

Landino, R. A., \& Owen, S. V. (1988). Self-efficacy in university faculty. Journal of Vocational Behavior, 33(1), 1-14. 
Lane, P. J., \& Lubatkin, M. (1998). Relative absorptive capacity and interorganizational learning. Strategic Management Journal, 19(5), 461-477.

Larkin, J. H. (1981). Enriching formal knowledge: A model for learning to solve textbook physics problems. In J. R. Anderson (Ed.), Cognitive skills and their acquisition (pp. 311-334) Hillsdale, NJ: Lawrence Erlbaum Associates.

Lawrence, J., \& Blackburn, R. (1985). Faculty careers: Maturation, demographic, and historical effects. Research in Higher Education, 22(2), 135-154.

Levin, S. G., \& Stephan, P. E. (1989). Age and research productivity of academic scientists. Research in Higher Education, 30(5), 531-549.

Linsky, A. S., \& Straus, M. A. (1975). Student evaluations, research productivity, and eminence of college faculty. Journal of Higher Education, 46(1), 89-102.

Long, R., Crawford, A., White, M., \& Davis, K. (2009). Determinants of faculty research productivity in information systems: An empirical analysis of the impact of academic origin and academic affiliation. Scientometrics, 78(2), 231-260.

Madjar, N., Oldham, G. R., \& Pratt, M. G. (2002). There's no place like home?: The contributions of work and non-work sources of creativity support to employees' creative performance. Academy of Management Journal, 45(4), 757-767.

March, J. G., \& Simon, H. A. (1958). Organizations. New York: Wiley.

Martindale, C. (1989). Personality, situation, and creativity. In J. A. Glover, R. R. Ronning, \& C. R. Reynolds (Eds.), Handbook of creativity (pp. 211-215). New York: Plenum.

Maske, K. L., Durden, G. C., \& Gaynor, P. E. (2003). Determinants of scholarly productivity among male and female economists. Economic Inquiry, 41(4), 555-564.

McGee, G. W., \& Ford, R. C. (1987). Faculty research productivity and intention to change positions. The Review of Higher Education, 11(1), 1-16.

Mumford, M. D., \& Gustafson, S. B. (1988). Creativity syndrome: Integration, application, and innovation. Psychological Bulletin, 103(1), 27-43.

Norman, D. A., \& Rumelhart, D. E. (1975). Explorations in cognition. San Francisco: Freeman.

Oldham, G. R., \& Cummings, A. (1996). Employee creativity: Personal and contextual factors at work. Academy of Management Journal, 39(3), 607-634.

Over, R. (1982). Does research productivity decline with age? Higher Education, 11(5), 511-520.

Parnes, S. J., \& Noller, R. B. (1972). Applied creativity: The creative studies project. Part II: Results of the two-year program. Journal of Creative Behavior, 6(3), 164-186.

Perry, R. P., Clifton, R. A., Menec, V. H., Struthers, C. W., \& Menges, R. J. (2000). Faculty in transition: A longitudinal analysis of perceived control and type of institution in the research productivity of newly hired faculty. Research in Higher Education, 41(2), 165-194.

Priest, A. G., \& Lindsay, R. O. (1992). New light on novice-expert differences in physics problem solving. British Journal of Psychology, 83(3), 389-405.

Quillian, M. R. (1968). Semantic memory. In M. Minsky (Ed.), Semantic information processing (pp. 227-270.) Cambridge, Mass.: MIT Press. 
Quillian, M. R. (1969). The teachable language comprehender: A simulation program and theory of language. Communications of the Association for Computing Machinery, 12(8), 459-476.

Redmond, M. R., Mumford, M. D., \& Teach, R. (1993). Putting creativity to work: Effects of leader behavior on subordinate creativity. Organizational Behavior and Human Decision Processes, 55(1), 120-151.

Santo, S. A., Engstrom, M. E., Reetz, L., Schweinle, W. E., \& Reed, K. (2009). Faculty productivity barriers and supports at a school of education. Innovative Higher Education, 34(2), 117-129.

Schoen, L. G., \& Winocur, S. (1988). An investigation of the self-efficacy of male and female academics. Journal of Vocational Behavior, 32(3), 307-320.

Schultz, J. B., \& Chung, Y. L. (1988). Research productivity and job satisfaction of university faculty. Journal of Vocational Education Research, 13(4), 33-48.

Scott, S. G., \& Bruce, R. A. (1994). Determinants of innovative behavior: A path model of individual innovation in the workplace. Academy of Management Journal, 37(3), 580-607.

Senge, P. M. (1990). The fifth discipline: The art and practice of the learning organization. New York: Currency Doubleday.

Shalley, C. E., Zhou, J., \& Oldham, G. R. (2004). The effects of personal and contextual characteristics on creativity: Where should we go from here? Journal of Management, 30(6), 933-958.

Sheehan, B. S., \& Welch, A. R. (1996). The Australian academic profession. In P. G. Altbach (Ed.), The international academic profession: Portraits of fourteen countries (pp. 231-280). San Francisco: Jossey-Bass.

Simon, H. A. (1985). What we know about the creative process. In R. L. Kuhn (Ed.), Frontiers in creative and innovative management (pp. 3-20). Cambridge, MA: Ballinger.

Snell, C., Sorenson, J., Rodriguez, J. J., \& Kuanliang, A. (2009). Gender differences in research productivity among criminal justice and criminology scholars. Journal of Criminal Justice, 37(3), 288-295.

Spilich, G. J., Vesonder, G. T., Chiesi, H. L., \& Voss, J. F. (1979). Text processing of domain-related information for individuals with high- and low-domain knowledge. Journal of Verbal Learning and Verbal Behavior, 18(3), 275-290.

Stein, M. I. (1991). Creativity is people. Leadership and Organizational Development Journal, 12(6), 4-10.

Taggar, S. (2002). Individual creativity and group ability to utilize individual creative resources: A multilevel model. Academy of Management Journal, 45(2), $315-330$.

Teodorescu, D. (2000). Correlates of faculty publication productivity: A crossnational analysis. Higher Education, 39(2), 201-222.

Tesluk, P. E., Farr, J. L., \& Klein, S. R. (1997). Influences of organizational culture and climate on individual creativity. Journal of Creative Behavior, 31(1), 27-41.

Tien, F. F., \& Blackburn, R. T. (1996). Faculty rank system, research motivation, and faculty research productivity: Measure refinement and theory testing. Journal of Higher Education, 67(1), 2-22. 
Tierney, P., Farmer, S. M., \& Graen, G. B. (1999). An examination of leadership and employee creativity: The relevance of traits and relationships. Personnel Psychology, 52(3), 591-620.

Van de Ven, A. H., \& Angle, H. L. (1989). An introduction to the Minnesota innovation research program. In A. H. Van de Ven, H. L. Angle, \& M. S. Poole (Eds.), Research on the management of innovation: The Minnesota studies (pp. 3-30). New York: Harper \& Row.

Vasil, L. (1992). Self-efficacy expectations and causal attributions for achievement among male and female university faculty. Journal of Vocational Behavior, 41(3), 259-269.

Volkwein, J. F., \& Carbone, D. A. (1994). The impact of departmental research and teaching climates on undergraduate growth and satisfaction. The Journal of Higher Education, 65(2), 147-167.

Voss, J. F., Greene, T. R., Post, T. A., \& Penner, B. C. (1983). Problem solving skill in social sciences. In G. H. Bower (Ed.), The psychology of learning and motivation (Vol. 17, pp. 165-213). New York: Academic Press.

Walberg, H. J., Rasher, S. P., \& Parkerson, J. (1980). Childhood and eminence. Journal of Creative Behavior, 13(4), 225-231.

Wanner, R. A., Lewis, L. S., \& Gregorio, D. I. (1981). Research productivity in academia: A comparative study of the sciences, social sciences, and humanities. Sociology of Education, 54(4), 238-253.

Wickens, C. D., Gordon, S. E., \& Liu, Y. 1997. An introduction to human factors engineering. New York: Longman.

Yong, L. M. S. (1994). Managing creative people. Journal of Creative Behavior, 28(1), $16-20$.

Zahra, S. A., \& George, G. (2002). Absorptive capacity: A review, reconceptualization, and extension. Academy of Management Review, 27(2), 185-203.

Zhou, J., \& Oldham, G. R. (2001). Enhancing creative performance: Effects of expected developmental assessment strategies and creative personality. Journal of Creative Behavior, 35(3), 151-167. 